\title{
LAKNAT BAGI PEZIARAH KUBUR (Kajian atas Hadis Ziarah Kubur Bagi Perempuan)
}

\author{
Sabil Mokodenseho \\ Sekolah Pascasarjana UIN Syarif Hidayatullah Jakarta \\ sabil.mokodenseho@gmail.com
}

\section{PENDAHULUAN}

Ziarah-secara harfiah, "kunjungan",1 sebuah gagasan yang mencakup semua tempat terhormat seperti kuburan dan tempat suci para wali, pohon, sumur, dan batu-juga secara universal populer, tetapi tidak memiliki otoritas Al-Quran. Dalam arti yang lebih sempit, istilah ziarah secara khusus menunjuk pada ziarah kubur (ziyarat al-qubūr), yang tercatat dalam hadis Rasulullah ${ }^{2}$

Merujuk dalam sejarah, awalnya, praktik ziarah kubur dilarang keras oleh Nabi Muhammad tetapi kemudian dihapuskan dengan izin untuk melakukannya. ${ }^{3}$ Mustafa Shalabi berpendapat bahwa perubahan itu terjadi terkait dengan tingkat literasi iman pada masa larangan dan izin. ${ }^{4}$ Larangan berziarah kubur tepat pada saat itu karena para sahabat Nabi masih baru dalam Islam, iman dan akidah mereka masih tipis. Kehidupan keislaman mereka masih dekat dengan jahìlīah yang menyembah patung dan berhala, bahkan orang-orang Yahudi yang tinggal di antara mereka telah menjadikan 272.

${ }^{1}$ Mohd Idris, Kamus Marbawi, juz I \& II, (Kairo: Mustafa al-Halby, 1350 H),

2 Thomas Leisten, "Between Orthodoxy and Exegesis: Some Aspects of Attitudes in The Shari'a Toward Funerary Architecture." Muqarnas Online 7, no. 1 (1989): 2-22. https://doi.org/10.1163/22118993-90000245; Mustafa Kabha, and Haggai Erlich, "Al-Ahbash and Wahhabiyya: Interpretations of Islam." International Journal of Middle East Studies 38, no. 4 (2006): 519-38. http://www.jstor.org/stable/4129146.

${ }^{3}$ Abdul Karim Zaydan, Al-Madkhal li Dirāsah al-Shari'ah al-Islāmīyyah, cet. 13 (Beīrūt: Mu'assasah al-Risālah, 1996), 96.

4 Muhammad Mustafa Shalabi, Al-Madkhal fi al-Ta'rif bi al-Fiqh al-Islāmī (Beīrūt: Dār al-Nahdah al-'Arabiyyah, 1985), 92. 
makam Nabi mereka sebagai tempat ibadah. ${ }^{5}$ Ketika keadaan dan lingkungan telah berubah, keyakinan dan iman para sahabat Nabi menguat dan segala bentuk patung dan berhala dihancurkan, aturan hukum itu dicabut dan kunjungan kubur didorong oleh syariat. ${ }^{6}$

Meski demikian, bukan berarti persoalan di atas jelas dan terang di kalangan umat, khususnya Muslim. Pasca Nabi wafat dan setelahnya, pro kontra seputar hukum ziarah kubur kerapkali mencuat dan melahirkan permusuhan. Hal ini disebabkan karena para pelaku ziarah kubur sering dituduh menyembah kuburan dan divonis syirik (sesat). ${ }^{7}$ Bahkan, salah-satu penyebab penghancuran situs bersejarah ${ }^{8}$ termasuk kuburan di Timur Tengah abad kontemporer, tepatnya di Yaman, sebagaimana dalam karya Engseng Ho diilhami oleh praktik ziarah dan berakar pada ketidaksepakatan atas isu-isu dasar yang terkait dengan budaya kuburan, memicu insiden penghancuran kuburan. ${ }^{9}$

Beberapa 'ulamā' telah menolak keaslian hadis-hadis tentang kebolehan ziarah, dan makna yang lain telah ditafsirkan dengan berbagai cara. Keyakinan dan ritual yang terkait dengan ziarah dalam banyak kasus menyebabkan ketegangan dengan para 'ulamā' yang

${ }^{5}$ Muhammad bin Abdullah al-Shawkani, Nayl al-Awtar, "Kitab al-Jana'iz": Bab al-Nahy 'an Ittikhadh al-Masajid wa al-Sarj fi al-Maqbarah, no. hadīth 1481 (Beīrūt: Dār al-Kutub al-'Ilmiyyah, 1995), 98.

${ }^{6}$ Al-Tirmidzī, Sunan al-Tirmidzī, "Kitab al-Jana'iz": Bab Ma Ja'a fi al-Rukhsah fi Ziyarah al-Qubūr, no. hadīth 1054 (Riyadh: Maktabah al-Ma'arif, 1996), 250.

7 Darsitun Darsitun, Khariri Khariri, and Darojat Darojat, "Women's Grave Perspective of Hadis." Journal of Hadith Studies 3, no. 1 (2020), 14-22. https://doi.org/10.32506/johs.v3i1.545. Lihat juga, Ebenhaizer I. Nuban Timo, "The Tradition of Visiting the Graveyard: A Theological Study on the Ways of Timorese Christians Honoring and Remembering the Dead." In International Conference on Religion and Public Civilization (ICRPC 2018), (Atlantis Press, 2019): 1621. https:/ / doi.org/10.2991/icrpc-18.2019.4; Leor Halevi, "Wailing for the Dead: The Role of Women in Early Islamic Funerals." Past E Present, no. 183 (2004): 3-39. https://www.jstor.org/stable/3600859.

8 Lihat, misalnya, sebuah artikel oleh salah satu penentang paling vokal terhadap penghancuran situs-situs bersejarah: Irfan al-Alawi, "The Destruction of Holy Sites in Mecca and Medina." Islamica Magazine (2006).

${ }^{9}$ Lihat Engseng Ho, The Graves of Tarim: Genealogy and Mobility across the Indian Ocean (Berkeley: University of California Press, 2006), 5-7. 
mengutuk ziarah kubur. Perdebatan dan perpecahan yang sengit juga muncul segera setelah kebangkitan Islam seputar pertanyaanpertanyaan seperti legalitas membangun kubah di atas kuburan; jenis ucapan, seperti doa dan permohonan, diperbolehkan di kuburan; kepatutan berdoa langsung kepada orang yang telah wafat, dan mencari syafaat atas nama diri sendiri atau orang lain; apakah diperbolehkan melakukan kontak fisik dengan kuburan; dan ketinggian maksimum di mana kuburan dapat didirikan tanpa menjadi berhala, ${ }^{10}$ termasuk yang menjadi tema tulisan ini, yakni diperbolehkannya wanita mengunjungi kuburan.

Larangan atas praktik ziarah kubur oleh 'ulamā',11 misalnya dikemukakan oleh salah satu ahli hukum dan teolog Islam abad pertengahan paling terkenal, yang pengaruhnya masih terasa dalam wacana Sunni saat ini, Ibn Taīmīyyah (661-728 H). ${ }^{12}$ Ibn Taīmīyyah mengategorikan penyembah kubur sebagai orang yang disesatkan oleh setan seperti halnya setan menyesatkan orang-orang musyrik Arab. ${ }^{13}$ Pendapatnya inilah yang kemudian membawanya ke pemenjaraan yang terakhir karena pendapat hukumnya yang dilaporkan mencela ziarah ke makam Nabi. ${ }^{14}$

Ibn Taīmīyyah dikalahkan oleh lawan-lawannya, 'ulamā' Mesir dan Suriah, dan meninggal di penjara bersama dengan pendapat hukumnya yang mengutuk ziarah kubur dan kepercayaan pada syafaat. Meskipun kegagalannya untuk menang di masa hidupnya, bagaimanapun, Ibn Taïmīyyah meninggalkan warisan yang berpengaruh untuk generasi berikutnya-yang, pada abad-abad berikutnya, masih merasa terdorong untuk terlibat dalam perdebatan

10 Ondrej Beranak and Pavel Tupek, "From Visiting Graves to their Destruction: The Question of Ziyara Through the Eyes of Salafis." Crown Papers, 2009,1-40.

11 Lihat Mikkel Bille, "Dealing with Dead Saints." In Taming Time, Timing Death, (Routledge, 2016): 153-172.

12 Ibn Rajab, Al-Dhayl 'ala Tabaqat al-Hanabila IV (al-Riyad: Maktabat al‘Ubaykan, 2005), 518.

13 Ibn Taīmīyyah, Al-Radd 'ala al-Mantiqiyyin, jilid 1 (Pakistan: Dār alTarjaman al-Sunnah, 1976), 105.

${ }^{14}$ Ibn Rajab, al-Dhayl 'ala tabaqat..., 518. 
serupa, baik dalam membantah argumennya atau membela. Warisan spiritualnya, mungkin terlalu disederhanakan dan apakah dibenarkan atau tidak, menemukan tempat yang subur dalam diri Muhammad bin 'Abd al-Wahhāb (1115-1206 H), dan juga telah diambil alih oleh Salafi saat ini. ${ }^{15}$ Praktik ziarah kubur dilarang sebab dalam praktiknya menurut 'Abd Wahhāb sebagaimana dikutip alSa'dī tidak jarang para penyembah kubur itu takut kepada pemilik kubur dikarenakan ia tidak disenangi atau ia marah kepadanya. ${ }^{16}$ Sebelum 'Abd al-Wahhāb, Ibn al-Qayyīm (691-751 H) juga telah mengatakan hal yang serupa bahwa menjadikan kuburan sebagai tempat yang paling utama dan yang dicintai Allah SWT. adalah salah satu di antara bentuk kerusakan. ${ }^{17}$

Terkait larangan ziarah kubur, baik laki-laki maupun perempuan, pernah juga difatwakan oleh Ibn Baz yang ketika itu masuk dalam Komite Tetap (al-Lajna al-da'ima) Arab Saudi. Bagi lakilaki, dianjurkan (mustahabb), menurut Ibn Baz mereka bisa mengunjungi makam Nabi dan para sahabatnya-tetapi tidak diizinkan untuk menyentuh atau mencium dan mengelilingi kuburan. Namun, Ibn Baz, bertentangan dengan kepercayaan yang diterima secara umum, menegaskan bahwa mengunjungi makam Nabi tidak wajib bagi umat Islam dan sama sekali bukan bagian yang sah dan wajib dari haji. ${ }^{18}$ Sementara bagi perempuan, dilarang dengan alasan perempuan "tidak sabar", dan kunjungan perempuan ke kuburan atau menghadiri pemakaman dapat menimbulkan godaan (fitnah). ${ }^{19}$ Meski demikian, para peziarah kubur tetap tidak

15 Beranak and Tupek, "From Visiting Graves to their Destruction: The Question of Ziyara Through the Eyes of Salafis," 1-40.

16 Abdurrahman ibn Nashir al-Sa'dī, Al-Qaul as-Sadid 'ala Syarkh al-Taūhid, jilid 1 (Daar al-Tsabat, 2014), 120.

17 Ibn al-Qayyīm, Ighatsah al-Lahfan (Jeddah: Majma'a al-Fiqh al-Islāmī, 1432), 198.

18 'Abd al-'Aziz ibn 'Abdallah Ibn Baz, Al-Tahqiq wa al-Idah li-Kathir min Masa'il al-Hajj wa al-Umra wa al-Ziyara 'ala Daw' al-Kitab wa al-Sunna (Mekah: Mu'assasat Makka lil-Tiba'a wa al-I'lam, 1974), 82.

19 'Abd al-'Aziz ibn 'Abdallah Ibn Baz, Al-Fatawa al-Muhimma (Al-Qahira: Dār al-Ghad al-Jadīd, 2006), 473. 
terima dituduh menyembah kuburan. Bukan tanpa dasar, mereka juga mempunyai dasar pembenaran dengan berpegang pada dalildalil anjuran ziarah kubur, yang menjadi salah satu dari pembahasan tulisan ini.

Dengan berpegang pada dalil dan argumen masing-masing, antara satu golongan dengan golongan lainnya saling merasa benar dan masing-masing mencari pembenaran dari teks-teks agama (AlQuran dan hadis). Bahkan bukan hanya persoalan tatacara pelaksanaannya saja yang dipersoalkan, akan tetapi para pelakunya pun menjadi sasaran vonis laknat, khususnya bagi peziarah perempuan.

Golongan yang menolak ziarah kubur bagi perempuan, menjadikan hadis-hadis dengan redaksi laknat sebagai pembenaran atas keyakinan mereka. Di sisi lain, sebagian golongan menganggap ziarah kubur adalah bagian dari tradisi perjalanan seorang Muslim seperti halnya haji, hijrah dan rihlah. ${ }^{20}$ Sehingga mereka meyakini ziarah kubur bisa dilakukan selama tidak mendatangkan syirik dan sebagainya. Golongan yang terbiasa melakukan ziarah kubur juga menganggap praktik ini sebagai bentuk wasilah dalam melangitkan hajat-hajat mereka melalui para wali Allah yang sudah wafat, yang diketahui semasa hidup mereka adalah orang berilmu dan menjadi suri tauladan bagi umat. Bahkan peziarah dapat mengambil pelajaran dan peringatan supaya hidup ingat akan mati dan nasib di kemudian hari, akhirat. ${ }^{21}$ Golongan yang kedua ini juga tidak mau kalah dan tinggal diam.

Persoalan ini harus didudukkan dengan semestinya, bukan mencari pembenaran untuk menguatkan kelompok atau madhab masing-masing, melainkan mencari kebenaran dengan mengesampingkan arogansi dan fanatisme golongan ('Ashabiyah). Untuk mencari kebenaran, tentu diperlukan ketelitian dan

20 Dale F. Eickelman, and James P. Piscatori, (eds.), Muslim Travellers: Pilgrimage, Migration, and the Religious Imagination IX (Berkeley \& Los Angeles: University of California Press, 1990), xii.

${ }^{21}$ Hariz al-Farizi, Rahasia Ziarah Kubur (Jakarta: al-Sofwa Subur, 2003), 10. 
kecermatan di dalam mengurai dalil-dalil seputar ziarah kubur, khususnya bagi perempuan. Karena tidak jarang, secara zahir teksteks hadis terkesan saling bertentangan ( $\left(a^{\prime} \bar{a} r u d h\right)$, dan baik yang suka melakukan ziarah maupun yang anti ziarah akan menemukan pembenaran atas keyakinannya masing-masing. Maka, dibutuhkan kajian yang komprehensif di dalam mendudukkan masalah ini dengan sebisa mungkin menggunakan pendekatan komparatifkompromistik (al-muqaranah wa al-jam'u).

Tulisan ini memusatkan perhatiannya pada redaksi dan status hadis tentang laknat ziarah kubur bagi perempuan, serta mencari jalan keluar atas kontradiksi hadis-hadis laknat dengan hadis kebolehan ziarah kubur termasuk hukum ziarah kubur bagi perempuan menurut para 'ulamā'.

\section{PEMBAHASAN}

\section{Riwayat Hadis Laknat Ziarah Kubur Bagi Perempuan}

Hadis yang berkaitan dengan laknat bagi perempuan yang menziarahi kuburan terdapat beberapa riwayat. Di antara riwayatriwayat tersebut misalnya, dalam kitab Al-Jāmi' al-Kabìr Sunan alTirmidzī리 karya Imām al-Tirmidzī (w. 279 H), dalam Sunan Ibn Mājah karya Imām Ibn Mājah (w. $273 \mathrm{H}){ }^{23}$ dan dalam Musnad al-Imām A ḥmad Ibn Hanbal karya Imām Ibn Ḥanbal (w. 241 H). ${ }^{24}$ Berikut adalah uraian berdasarkan asal sanadnya.

Pertama, dari Abū Huraīrah r.a.:

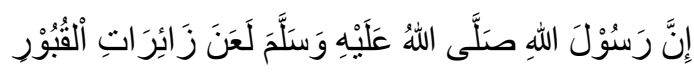

Artinya: "Sesungguhnya Rasulullah melaknat para wanita yang menziarahi kuburan."

22 Muhammad bin 'Isya bin Saurah al-Tirmidzī, Al-Jāmi' al-Kabìr Sunan alTìrmidzī II (Bairut: Dār al-Gharby al-Islāmī, 1998), 362.

${ }^{23}$ Abū 'Abdillāh Muhammad ibn Yazīd Ibn Mājah, Sunan Ibn Mājah I (Dār Ihyā' al-Kutub al- 'Arabiyyah, t.th.), 502.

${ }^{24}$ Abū 'Abdillāh Aḥmad Ibn Muhammad Ibn Ḥanbal, Musnad al-Imām Aḥmad Ibn Hanbal XIV (Kairo: Muasasatu al-Risālah, 2001), 164. 
Hadis di atas diriwayatkan oleh al-Tirmidzī dan dishahihkan oleh Ibn Ḥibbān ${ }^{25}$ dan juga diriwayatkan oleh Ibn Mājah dalam Sunan Ibn Mājah. Menurut Imām al-Tirmidzī, status hadis ini adalah ḥasan. ${ }^{26}$ Bahkan dalam riwayat lain, al-Tirmidzī menyebut hadis ini sebagai hadith hasan-shahì karena jalur periwayatannya banyak.

Kedua, dari Ibn Abbās r.a:

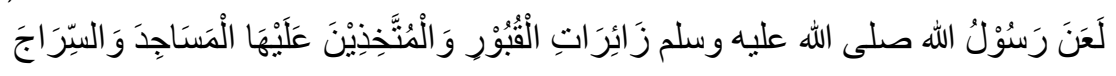

Artinya: "Rasulullah melaknat para wanita yang menziarahi kuburan dan menjadikannya sebagai masjid serta (menyalakan) lentera (lampu)."

Hadis di atas diriwayatkan oleh an-Nasai dalam Bab al-Janaiz (hadis no 2039), Abū Daūd dalam Bab al-Janaiz (hadis no. 3236), alTirmidzī dalam Bab Shalat (hadis no. 320), dan Ibn Mājah dalam Bab al-Janaiz (hadis no. 1571). Sanad hadis ini keseluruhannya dari Ibn Abbās. Imām Aḥmad dalam Musnadnya meriwayatkan dari Yahya, dari Syu'bah, dari Muhammad bin Jihadah, dari Abū Shaleh dari Ibn Abbās. Ada juga dari jalur riwayat Abū Daūd dari Muhammad bin Katsīr, dari Syu'bah, dari Muhammad bin Jihadah, dari Abū Shaleh dari Ibn Abbās. ${ }^{27}$ Kecuali Ibn Ḥibbān meriwayatkan dengan sanad yang lain dari jalur Abū Huraīrah r.a., yaitu: diriwayatkan dari Muhammad bin Abdullah bin Junaid, dari Qutaibah bin Said, dari Abū 'Awanah, dari Umar bin Abī Salamah, dari bapaknya, dari Abū Huraīrah r.a. Adapun status hadis ini adalah termasuk hadith hasan.

Ketiga, dari Abū Huraīrah r.a.:

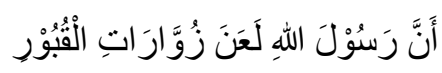

Artinya: "Sesungguhnya Rasulullah melaknat para wanita yang sering menziarahi kuburan."

${ }^{25}$ Ibn Hajar al-'Asqalani, Bulūgh al-Marām (Indonesia: Dār Ihyā' al-Kutub al'Arabiyyah), 122.

${ }^{26}$ Ḥasan bin Ali al-Qanuji al-Bukhārī al-Hindi, Fath al- 'Allam li Syarh Bulügh al-Marām I (Beīrūt: Dār al-Kutub al-Ilmiyah, 1997), 490.

${ }_{27}$ Abū Daūd Sulaiman bin al-Asy'ats al-Sijastani, Sunan Abū Daūd II (Beīrūt: Dār al-Fīkr, 2011), 256. 
Hadis di atas diriwayatkan oleh Ibn Mājah no. 1641, 1642, 1643, al-Tirmidzī no. 1076, dan Aḥmad no. 8904. Dari jalur Imām alTirmidzī, hadis ini diriwayatkan dari Qutaibah, dari Abū 'Awanah, dari Umar bin Abi Salamah, dari bapaknya, dari Abū Huraīrah r.a. Setelah meriwayatkan hadis ini, Imām al-Tirmidzī dalam kitab Sunannya mengatakan bahwa status hadis ini adalah hadith hasanshahih. ${ }^{28}$

Ada juga yang menggunakan redaksi:

أَنَّ رَسُوْلَ اللهِهَ قَالَ: لَعَنَ اللهُ زُوَّارَاتِ الْقُقُوْرِ

Artinya: "Allah melaknat para wanita yang sering menziarahi kuburan." 29

Al-Qurthūbī dalam karya al-'Asqalani menjelaskan maksud dari kata laknat dalam hadis di atas, ditujukan kepada para wanita yang sering mendatangi kuburan sebagaimana lafazh hadisnya menggunakan sighah mubalaghah. ${ }^{30}$

Sementara Aḥmad ibn Hanbal meriwayatkan dengan dua redaksi: (1) Redaksi dari Abū Huraīrah r.a. menggunakan zuwwārāat, demikian juga riwayat dari Hassan. (2) Redaksi dari Ibn Abbās dengan menggunakan lafazh zäirāt.

\section{Analisis Sanad Hadis tentang Laknat Ziarah Kubur}

Beberapa sanad hadis tentang laknat ziarah kubur yang dapat dikemukakan yaitu; (1) Aḥmad ibn Hanbal, al-Tirmidzī dan Ibn Mājah meriwayatkan hadis larangan ziarah kubur bagi perempuan dengan tiga jalur: jalur Abū Salamah, dari Abū Huraīrah; jalur Abū Shaleh, dari Ibn Abbās; dan, jalur Abdurrahman bin Ḥassan, dari bapaknya. (2) riwayat Abū Daūd. (3) riwayat Nasai. (4) riwayat Abū Daūd al-Tayalisi, dari Ibn Abbās. (5) Ibn Hịbān di dalam kitab

28 Muhammad 'Isya bin Saurah al-Tirmidzī, Sunan al-Tirmidzī (Riyadl: Maktabah al-Ma'arif li al-Nasyr wa al-Tawzi'), 250.

${ }^{29}$ Mahmud bin Ahmad al-Aini, 'Umdah al-Qari Syarh Shahīh al-Bukharī VIII (Beīrūt: Dār al-Kutub al-Ilmiyah, 2001), 100.

${ }^{30}$ Ibn Hajar al-'Asqalani, Fath al-Bārì Syarh Shahīh al-Bukharī III (Kairo: Dār alBayan al-'Arabi, 2007), 174. 
shahihnya, dari Abū Huraīrah dan Ibn Abbās. (6) Al-Hākīm, dari Hassan bin Tsābìt. ${ }^{31}$

Dari banyaknya jalur periwayatan sebagaimana di atas, maka sesungguhnya secara garis besar bisa difokuskan menjadi dua, yaitu:

Pertama, jalur riwayat Ibn Abbās. Pada jalur riwayat Ibn Abbās, perawi Abū Shaleh masih diperdebatkan soal namanya yang sebenarnya, di kalangan 'ulamā'. Perbedaan pendapat seputar nama sebenarnya dari Abū Shaleh mengerucut menjadi dua pendapat, yaitu: (1) Mizan al-Bashri Abū Shaleh. Pendapat ini dinyatakan, di antaranya, oleh Ibn Hibbān dalam kitab shahihnya; dan (2) Badzam, budak Ummu Hani', atau ada juga yang menyebut Badzan (nun). Pendapat ini dianut oleh Imām al-Hākīm, Abdul Haq al-Isybili, Ibn al-Qatthān, Ibn 'Asakir, al-Mundzīr, Ibn Dahīyah, dan lain sebagainya. ${ }^{32}$

Dengan dua kemungkinan nama Abū Shaleh di atas, riwayat hadis la'ana zäirāt al-qubūr tetap dianggap hadis shahīh, baik yang dimaksud Abū Shaleh adalah Mizan maupun Badzam. Terkait nama Abū Shaleh, Ibn Hatìm mengatakan dalam al-Jarah wa al-Ta'dil: "Aku tidak melihat satupun dari sahabat-sahabatku yang meninggalkan Abū Shaleh, budak Ummu Hani', dan tidak satupun aku mendengar dari orang-orang mengatakan yang bukan-bukan tentang dirinya."33 Bahkan, Sa'id, Zaidah, dan Abdullah bin Utsman tidak meninggalkan (riwayat darinya). Begitu pun dengan Yahya bin Ma'in berkata: “Tidak ada masalah dengan Abū Shaleh, budak Ummu Hani', karena ketika al-Kalbi meriwayatkan darinya, maka itu menandakan tidak ada masalah..."

${ }^{31}$ Nama lengkapnya adalah Abdurrahman bin Hassan bin Mundzir bin Amr bin Haram al-Anshari. Ibn Ma'in menyebutkan bahwa ia termasuk tabi'in dan ahli hadis di Madinah. Ibn Sa'ad mengatakan ia termasuk penyair yang sedikit meriwayatkan hadis. Namun, Ibn Ḥibbān memasukkannya ke dalam kitab al-Tsiqatnya. Lihat al-Tahdzìb IV. 32.

${ }^{32}$ Lihat Ibn Hajar al-Asqalani, Tahdzīb al-Tahdzìb fì Rijāl al-Hadìts I (Beīrūt: Dār al-Kutub al-Ilmiyah, 2004), 391.

33 Ibn Ab̄i Hatīm, Al-Jarah wa Al-Ta'dil (Beīrūt: Dār Ihyā' al-Turath al'Arabiyyah, 1952). 
Demikianlah komentar para 'ulamā' hadis terkait dengan kredibilitas Abū Shaleh, budak Ummu Hani'. Bahkan Aḥmad Syakir dalam Hasyiahnya pada kitab Musnad Imām Aḥmad: "Yang benar (faktanya), Abū Shaleh, budak Ummu Hani' adalah tsiqah (terpercaya). Tidak ada hujah bagi yang melemahkannya (mendhaifkannya)..." jika ditinjau dari aspek sanadnya, maka menurut Aḥmad Syakir, hadis la'ana zäirāt al-qubūr termasuk hadis shahīh. Dengan demikian, al-Tirmidzī, al-Baghawi, Ibn Hajar dan Ahmad Syakir (dalam Syarah al-Tirmidzì) menganggap status hadis yang diriwayatkan oleh Qutaibah dari Abdul Warits bin Said, dari Muhammad bin Jihadah, dari Abī Shaleh, dari Ibn Abbās adalah hasan.

Kedua, jalur riwayat Abū Huraīrah r.a. Ibn Hibbān berkata: "Meriwayatkan kepada kami Muhammad bin Abdullah bin Junaid, dari Qutaibah bin Said, dari Abū 'Awanah, dari Umar bin Abī Salamah, dari bapaknya, dari Abū Huraīrah." 34 Umar di sini adalah Umar bin Salamah bin Abdurrahman bin 'Auf saudara Muslim. Abū Hatim berkata: "Menurutku, dia (Umar) adalah orang yang shaleh dan jujur, yang menulis hadisnya dan tidak ada bukti bahwa ia menyalahi sebagiannya. Ad-Dzahabi berkata: "Imām al-Tirmidzī menshahihkan hadis la'ana Rasulullah zuwwaraat al-qubūr yang diriwayatkan olehnya (Umar)." Namun Abdul Haq mengkritiknya dengan mengatakan bahwa Umar adalah dha'if. Ibn Ma'in mengatakan dalam riwayat Ahmad bin Abi Khatsimah bahwa tidak ada masalah dengan Umar. Dan Ibn Hibbān memasukkan dalam kategori perawi-perawi yang terpercaya (tsiqāt; 'ādil dan dhābith). Ibn Hajar dalam al-Tahdzib-nya mengatakan bahwa Umar adalah orang yang sangat jujur namun keliru. Dengan ungkapan Ibn Hajar ini, kita tahu bahwa Umar walaupun (mungkin) keliru, namun kaitannya dengan hadis ini, karena diriwatkan dari banyak jalur maka Umar dalam meriwayatkan hadis ini tidak keliru. Sehingga bisa

34 Muhammad bin Khibban bin Aḥmad, Masyāhir al-'Ulamā al-Amṣor wa A'lāmu Fuqahā al-Aqthār I (Kairo: Dār al-Wafā', 1411 H), 35. 
disimpulkan bahwa hadis tentang laknat ziarah kubur bagi perempuan adalah shahih. ${ }^{35}$

\section{Riwayat Hadis tentang Kebolehan Ziarah Kubur}

Di samping hadis-hadis yang melaknat perempuan melakukan ziarah kubur, terdapat banyak hadis yang redaksinya membolehkan ziarah kubur secara umum. Di antara hadis-hadis yang membolehkan ziarah kubur adalah sebagai berikut:

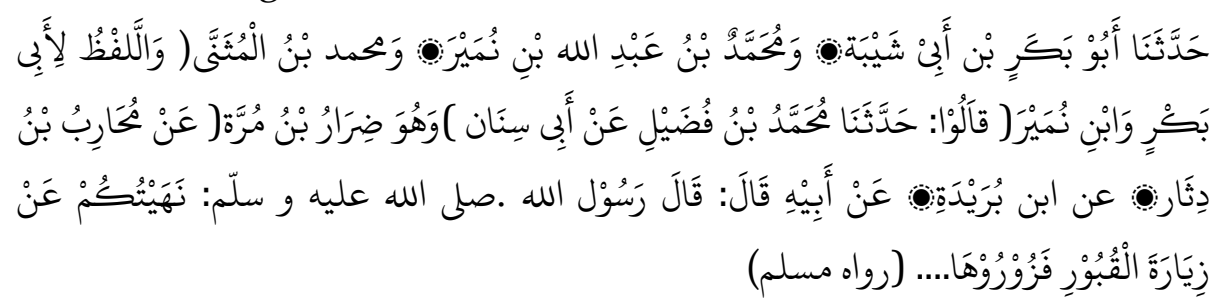

Artinya: "Telah menceritakan kepada kami Abū Bakar bin Abi Syaibah dan Muhammad bin Abdullah bin Numair dan Muhammad bin al-Mutsanna (lafadznya dari Abū Bakar dan Ibn Numair), mereka berkata: meriwayatkan kepada kami Muhammad bin Fudhail dari Abū Sinan (yaitu Dhirar bin Murrah) dari Muharib bin Ditsar, dari Ibn Buraidah, dari bapaknya, ia berkata: Rasulullah bersabda: "Aku melarangmu dari ziarah kubur, maka berziarahlah kamu sekalian ke kuburan." (HR. Muslim). ${ }^{36}$

Abū Daūd dan an-Nasai menambahkan dari hadis Anas redaksi

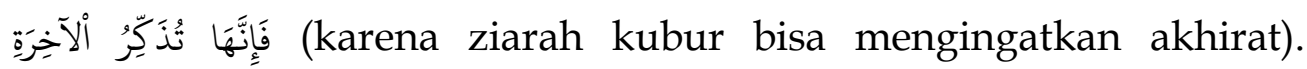

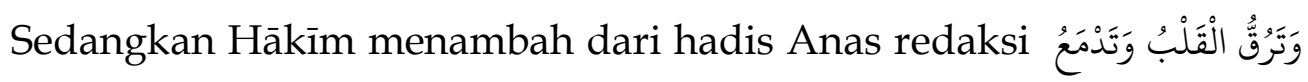
الْعَيْن فَلَا تَقُوُلُوُا هَجْرًا (dan melembutkan hati dan meneteskan air mata, dan janganlah kalian berkata dengan perkataan yang keji), dan riwayat lain dari Hākīm dari hadis Ibn Mas'ud menambahkan redaksi فَاِنَّها تُزِْهد فِ الدُنْيَا (karena ziarah kubur menyebabkan tidak suka dunia). Adapun redaksi dari Muslim dari hadis Abū Huraīrah r.a. dengan status

35 Bakar bin Abdullah Abū Zaid, Juz'un fì Ziyarāt al-Qubūr. Lihat selengkapnya dalam www.du3at.com/islamicbooks/3qeedah.htm. Diakses pada 06 Juni 2021.

36 Abū Husein Muslim bin al-Hajjaj, Shahīh al-Muslim I (Beīrūt: Dār al-Fīkr, 2011), 429-430. 


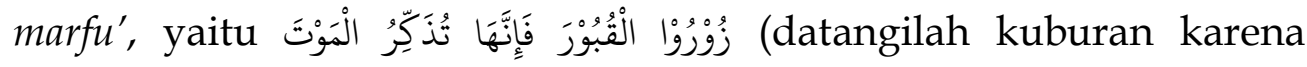
kuburan mengingatkan kematian). ${ }^{37}$

Ada juga hadis riwayat 'Aisyah r.a. yang menjelaskan tentang bolehnya melakukan ziarah kubur:

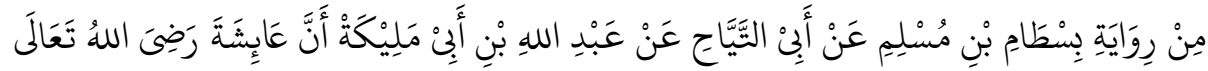

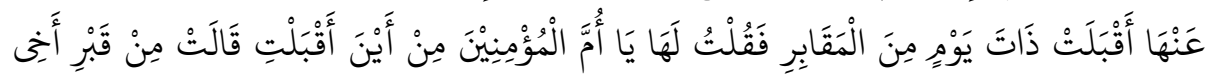

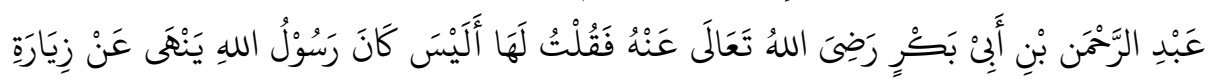

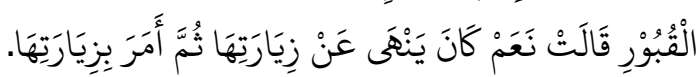

Artinya: "Dari riwayat Bistham bin Muslim dari Abū al-Tayyah dari Abdullah bin Abü Malikah bahwa sesungguhnya 'Aisyah r.a. suatu hari datang dari kuburan, maka aku bertanya kepadanya: "Wahai Ummul Mukminin, anda datang dari mana?" Beliau menjawab: "Dari kuburan saudaraku, Abdurrahman bin Abū Bakar r.a. Lalu aku bertanya lagi: "Bukankah Rasulullah telah melarang untuk mendatangi kuburan?" Beliau menjawab: "Benar, beliau memang dulu melarangnya, kemudian beliau memerintahkan untuk mendatangi kuburan." (HR. Hākīm dan Baihaqi). ${ }^{38}$

Begitu pula dengan hadis berikut ini:

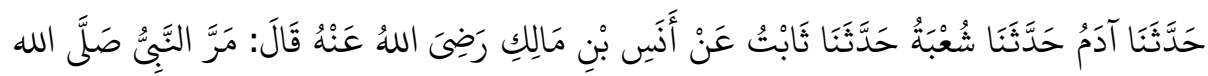

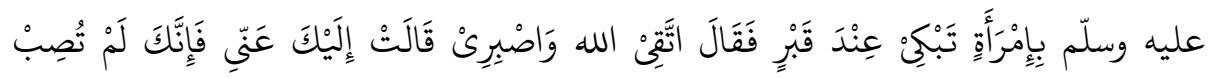

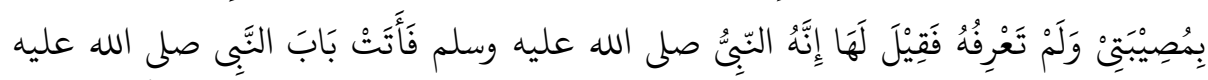

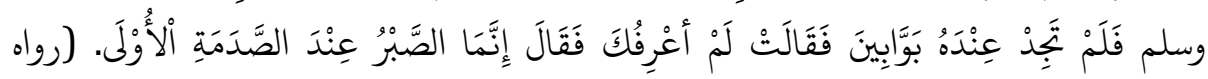
البخارى.)

Artinya: "Meriwayatkan kepada kami Adam, menceritakan kepada kami Syu'bah, menceritakan kepada kami Tsabit, dari Anas bin Malik r.a., ia berkata: Nabi lewat bertemu dengan seorang perempuan sedang menangis di samping kuburan. Maka beliau berkata: "Bertakwalah kepada Allah dan bersabarlah!" Perempuan tersebut menjawab: "Menyingkirlah dariku karena engkau tidak tertimpa musibah sepertiku-perempuan tersebut tidak mengetahui bahwa itu adalah Nabi-Dikatakan kepadanya bahwa sesungguhnya dia itu

37 Al-'Asqalānī, Fath al-Bārī..., III, 173.

38 Al-Hākīm: 1/376, al-Baihaqi: 4/78 (al-Maktabah al-Syamilah). 
Nabi, maka perempuan tersebut mendatangi pintu (rumah) Nabi. Dia tidak mendapati penjaga di rumah beliau. Dia berkata: "Aku tidak mengetahui bahwa itu engkau," Maka Nabi berkata: "Kesabaran itu hanyalah di awal musibah." (HR. Bukhārī no. 1283; Muslim no. 2179. lafadz hadis ini milik Bukhārī). ${ }^{39}$

Dan juga dengan hadis ini:

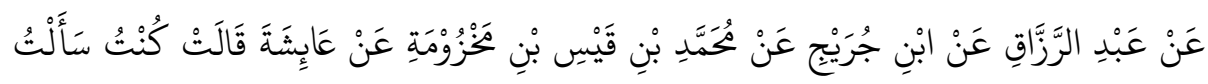

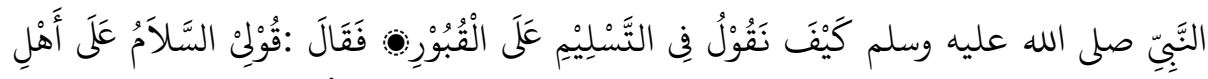

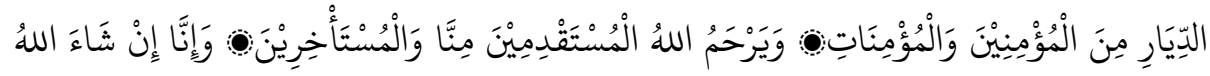

بِكُعْم لَاحِقُوْنَ.

Artinya: Dari 'Abd al-Razzāq dari Ibn Juraīj dari Muhammad bin Qāis bin Makhzumah, dari 'Aisyah, beliau berkata: "Aku bertanya kepada Nabi: Apa yang kami ucapkan ketika mendatangi kuburan?" Nabi Menjawab: "Ucapkanlah Assalamu'alaikum (semoga kesejahteraan atas kalian) wahai penghuni kubur dari kaum lelaki yang beriman dan kaum perempuan yang beriman. Semoga Allah merahmati orang-orang yang datang lebih dahulu maupun yang datang belakangan diantara kalian. Sesungguhnya kami, Insyaallah akan menyusul kalian." (HR. Muslim no. 974).

Demikian juga bertentangan dengan hadis ini:

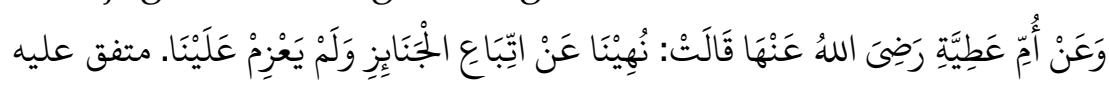
Artinya: Dari Ummu 'Athiyah r.a., berkata: "Kami dilarang untuk mengikuti jenazah (ke pemakaman), namun beliau tidak bersungguhsungguh (dalam melarang)." (HR. Bukhārī no. 1278; Muslim no. $35 / 54)$.

Dan bertentangan juga dengan hadis di bawah ini:

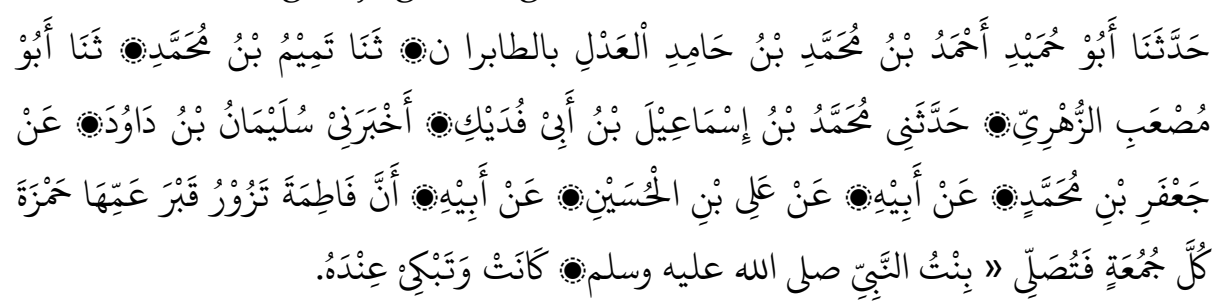

${ }^{39}$ Al-'Asqalānī, Fath al-Bārī..., III, 176. 
Artinya: "Diriwayatkan dari Abū Hamid Aḥmad bin Muhammad Ibn Hamid, dari Tamìm bin Muhammad, dari Mush'ab al-Zuhri, dari Muhammad bin Ismā'îl bin Ab̄̄ Fudaik, dari Sulaymān bin Daūd, dari Ja'far bin Muhammad, dari bapaknya, dari Ali bin Husein, dari bapaknya, dari Fatìmāh binti Muhammad, Rasulullah. Fatìmāh pergi menziarahi kuburan pamannya, Hamzah, setiap Jum'at. Ia melakukan shalat dan menangis di samping (kuburan pamannya)." (HR. Hākīm).

\section{Penyelesaian Kontradiksi Hadis}

Secara prinsip, hadis shahīh tidak mungkin bertentangan dengan dalil lainnya, seperti Al-Quran, sesama hadis, dan akal. Namun, dalam praktiknya, mencari makna dalam suatu hadis sering dijumpai antara dalil satu dengan dalil lainnya, terkesan kontradiksi satu sama lain. 'Ulamā' kemudian memberikan jalan keluar dalam menyelesaikan persoalan semacam ini.

Ketika dijumpai adanya kontradiksi antara hadis yang melaknat (melarang) ziarah kubur dengan hadis yang membolehkan, maka yang perlu dilakukan adalah dengan tahapan-tahapan, yaitu: Pertama, jika memungkinkan untuk dilakukan penggabungan dan kompromi (al-jam'u wat taufiq) antara kedua hadis yang saling bertentangan, maka harus dilakukan kompromi dan wajib mengamalkan (mengambil) kedua hadis yang terkesan saling bertentangan. Kedua, hadis yang tidak dapat dikompromikan karena alasan lain, maka dalam hal ini, bila kita mengetahui salah satunya adalah sebagai hadis yang nāsikh (menghapus hukum sebelumnya), maka hadis ini dikedepankan dan diamalkan serta meninggalkan yang sudah dihapus hukumnya (mansūkh). Jika tidak diketahui antara yang menghapus (nāsikh) dan yang dihapus (mansūkh), maka mengamalkan hadis yang rajah (unggul) setelah mentarjihnya dengan melihat sifat-sifat rawinya dan keunggulan mereka dalam lima puluh bidang tarjih (kualifikasi). Jika tidak memungkinkan dilakukan pentarjihan antara satu dengan yang lainnya, dan ini 
jarang, maka kita mendiamkan (tidak mengamalkan) keduanya hingga menjadi jelas mana yang unggul dari keduanya. ${ }^{40}$

\section{Analisis Hadis Ziarah Kubur dalam Melahirkan Hukum}

Dari perbedaan redaksi hadis tentang ziarah kubur bagi perempuan sebagaimana dijelaskan pada bagian awal, yang terkesan bertentangan satu sama lainnya, maka sulit dihindari perbedaan pendapat seputar hukum perempuan mendatangi kuburun. Adapun kemungkinan-kemungkinan munculnya perbedaan pendapat tersebut sebagaimana berikut:

Pertama, haram, dengan berpegang pada redaksi hadis yang diriwayatkan oleh Abū Huraīrah r.a. yang melaknat para perempuan berziarah kubur (la'ana Rasulullah zaairaat al-qubür).

Kedua, ditafsil (dispesifikasi); (1) haram apabila perempuan tersebut sering mendatangi kuburan dengan berpegang pada redaksi hadis la'ana Allah/Rasulullah zuwwarāt al-qubūr (para wanita yang sering ziarah kubur). Artinya, laknat (larangan) dalam hadis tersebut berlaku hanya kepada wanita yang sering mendatangi kuburan; (2) boleh, apabila tidak sering menziarahi kuburan (mafhūm mukhālafāh); (3) atau sekurang-kurangnya makruh, dengan argumentasi bahwa perempuan itu kurang sabar dan sering bersedih (melihat 'illät).

Ketiga, boleh, dengan argumentasi bahwa hadis pelaknatan tersebut berlaku sebelum adanya dispensasi dari Rasulullah untuk ziarah kubur, sebagaimana redaksi hadis riwayat Abū Baridah, Sayyidah 'Aisyah dan Anas bin Malīk, Ummu 'Athiyah dan Sayyidah Fatīmāh.

\section{Komentar 'Ulamā' tentang Hukum Ziarah Kubur bagi Perempuan}

Di bawah ini adalah penjelasan soal perbedaan pendapat seputar hukum ziarah kubur bagi perempuan menurut jumhur 'ulamā' termasuk pandangan empat madhab:41

${ }^{40}$ Mahmud al-Thahhan, Taisìr Musthalah al-Hadìts (Surabaya: Dār al-Kutub alIslāmī, 2008), 57-58.

${ }^{41}$ Lihat Tim Penyusun, Al-Mausū'ah al-Fiqhiyah al-Kuwaitiyah, cet. 2 (Kūwaìt: Wazarah al-Awqaf wa al-Syu'un al-Islāmīyyah, 1983), 88. 
1. Mayoritas 'ulamā' berpendapat ziarah kubur bagi perempuan hukumnya makruh dengan argumentasi لَعَنَ اللهُ زَوَّارَاتِ الْقُبُور dan dengan pertimbangan bahwa perempuan memiliki kelembutan hati (sehingga mudah menangis), mudah bersedih hati, kurang mampu menahan beban musibah, yang hal ini bisa membuatnya menangis dan meninggikan suaranya (menjerit).

2. Madhab Hanafī berpendapat dalam qaūl ashah-nya (pendapat yang paling shahīh), bahwa hukum perempuan melakukan ziarah kubur adalah sunah sebagaimana laki-laki, dengan argumentasi:

$$
\text { كُنْتُ نَهَيْتُكُمْ عَنْ زيَارَة الُْبُورُ فزوروها }
$$

3. Madhab Mālīkī berpandangan bahwa hukum ziarah kubur bagi perempuan adalah makruh sebagaimana argumentasi jumhur 'ulamā'. Hanya saja, Ibn 'Abidin menganggap baik ziarah kubur bagi perempuan (tawfiqun hasanun).

4. Mazhab Syafi'i berpendapat bahwa ziarah kubur bagi perempuan hukumnya adalah makruh sebagaimana argumentasi jumhur 'ulamā'. Hanya saja Imām Ramli memberikan perincian:

Pertama, tidak boleh, apabila setiapkali ziarah kubur menyebabkan bersedih dan membuatnya menangis kembali. Disinilah berlaku hadis:

$$
\text { لَعَنَ اللهُ زُوََّراتِ الْقُبُور }
$$

Kedua, boleh, apabila tujuan ziarah kubur untuk mengambil pelajaran dan sebagai bentuk kasih sayang dan tabarruk dengan menziarahi kuburan orang-orang shaleh seperti Nabi, wali dan kiai, tanpa harus menangis. Kebolehan ini berlaku bagi perempuan yang sudah tua. Adapun bagi perempuan yang masih muda, maka hukumnya makruh, seperti halnya menghadiri masjid untuk shalat berjemaah.

5. Menurut madhab Hanbali, ziarah kubur bagi perempuan hukumnya ditafsil: 
Pertama, makruh, dengan argumentasi hadis Nabi:

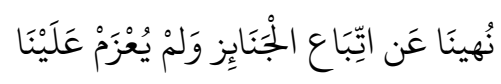

Kedua, haram, apabila diyakini akan menimpa pada diri perempuan sesuatu yang diharamkan, karena dianggap termasuk ke dalam kategori hadis nabi:

$$
\text { لَعَنَ اللهُ زُوَّرَاتِ الفقُبُور }
$$

Ketiga, dianggap baik, apabila seorang perempuan berjalan melewati kuburan kemudian ia membacakan salam dan berdoa. Keempat, sunah, perempuan menziarahi kuburan Rasulullah dan para Nabi yang lain, dengan melihat keumuman dalil anjuran ziarah kubur:

$$
\text { كُنْتُ نَهَيْتُكُمْ عَنْ زيَارَة القُقُبُور فزوروها }
$$

\section{PENUTUP}

Kesimpulan tulisan ini adalah bahwa perbedaan redaksi hadis akan melahirkan perbedaan pendapat seputar ziarah kubur bagi perempuan. Maka, untuk menghasilkan rumusan hukum yang akurat dan akomodatif, sebisa mungkin dilakukan kompromisasi antara satu hadis dengan hadis lainnya. Dari penelusuran terhadap hadis-hadis yang berkaitan dengan hukum ziarah kubur bagi perempuan, ditemukan tidaklah tunggal, dan karena ketidaktunggalannya itu, meniscayakan atau melahirkan hukum yang berbeda-beda pula. Redaksi hadis yang melaknat perempuan ziarah kubur tidak bisa serta merta distempelkan kepada seluruh perempuan yang ziarah kubur karena ada banyak hadis yang mengisyaratkan perempuan dibolehkan menziarahi kuburan. Belum lagi, hadis pelaknatan kepada perempuan yang melakukan ziarah kubur dianggap sudah di-nasakh oleh hadis lainnya yang menganjurkan. Tentu, secara otomatis hadis yang melarang perempuan menziarahi kubur tidak berlaku lagi, kecuali 'illāt yang menyebabkan terlaknatnya perempuan terpenuhi. Oleh karena itu, penting untuk saling menghargai antara yang suka melakukan ziarah kubur dengan yang anti ziarah kubur. Argumentasi yang dapat dikemukakan adalah bahwa perbedaan madhab tidak boleh menjadi 
penyebab renggangnya jalinan ukhuwah antar sesama umat Islam, pun terhadap mereka yang anti ziarah kubur tidak perlu menyesatkan yang suka ziarah kubur, dan yang suka melakukan ziarah kubur hendaknya menjaga norma-norma agama agar tidak terjerumus kepada kesyirikan.

\section{REFERENSI}

Asqalani (al), Ibn Hajar. Tahdzìb al-Tahdzìb fì Rijāl al-Hadīts, I. Beīrūt: Dār al-Kutub al-Ilmiyah, 2004.

. Fath al-Bārī Syarh Shahīh al-Bukharī, III. Kairo: Dār al-Bayan al'Arabi, 2007.

. Bulūgh al-Marām. Indonesia: Dār Ihyā' al-Kutub al-'Arabiyyah.

Aḥmad, Muḥammad bin Khibban bin. Masyāhir al-'Ulamā al-Amșor wa

A'lāmu Fuqahā al-Aqthār, I. Kairo: Dār al-Wafā', $1411 \mathrm{H}$.

Aini (al), Mahmud bin Aḥmad 'Umdah al-Qari Syarh Shahīh al-Bukharì, VIII. Beīrūt: Dār al-Kutub al-Ilmiyah, 2001.

Alawi (al), Irfan. "The Destruction of Holy Sites in Mecca and Medina." Islamica Magazine, (2006).

Baz, 'Abd al-'Aziz ibn 'Abdallah Ibn. Al-Tahqiq wa al-Idah li-Kathir min Masa'il al-Hajj wa al-Umra wa al-Ziyara 'ala Daw' al-Kitab wa alSunna. Mekah: Mu'assasat Makka lil-Tiba'a wa al-I’lam, 1974.

. Al-Fatawa al-Muhimma. Al-Qahira: Dār al-Ghad al-Jadīd, 2006.

Beranak, Ondrej, and Pavel Tupek, "From Visiting Graves to their

Destruction: The Question of Ziyara Through the Eyes of Salafis." Crown Papers, (2009): 1-40.

Bille, Mikkel. "Dealing with Dead Saints." In Taming Time, Timing Death, (Routledge, 2016): 153-172.

Darsitun, D., Khariri Khariri, and Darojat Darojat, “Women's Grave Perspective of Hadis." Journal of Hadith Studies 3, no. 1 (2020): 1422. https:// doi.org/10.32506/johs.v3i1.545.

Eickelman, Dale F. and James P. Piscatori, (eds.), Muslim Travellers: Pilgrimage, Migration, and the Religious Imagination IX. Berkeley \&

Los Angeles: University of California Press, 1990.

Farizi (al), Hariz. Rahasia Ziarah Kubur. Jakarta: al-Sofwa Subur, 2003. 
Hajjaj (al), Abū Husein Muslim bin Shahīh al-Muslim I. Beīrūt: Dār alFīkr, 2011.

Hākīm (al): 1/376, al-Baihaqi: 4/78 (al-Maktabah al-Syamilah).

Halevi, Leor. "Wailing for the Dead: The Role of Women in Early Islamic Funerals." Past \& Present, no. 183 (2004): 3-39. https:/ /www.jstor.org/stable/3600859.

Ḥanbal, Abū 'Abdillāh Aḥmad Ibn Muḥammad Ibn. Musnad al-Imām Ahmad Ibn Hanbal XIV. Kairo: Muasasatu al-Risālah, 2001.

Hatīm, Ibn Abī. Al-Jarah wa Al-Ta'dil. Beīrūt: Dār Ihyā' al-Turath al'Arabiyyah, 1952.

Hindi (al), Ḥasan bin Ali al-Qanuji al-Bukhārī Fath al- 'Allam li Syarh Bulūgh al-Marām I. Beīrūt: Dār al-Kutub al-Ilmiyah, 1997.

Ho, Engseng. The Graves of Tarim: Genealogy and Mobility across the Indian Ocean. Berkeley: University of California Press, 2006.

Idris, Mohd. Kamus Marbawi, juz I \& II. Kairo: Mustafa al-Halby, 1350 $\mathrm{H}$.

Kabha, Mustafa, and Haggai Erlich, "Al-Ahbash and Wahhabiyya: Interpretations of Islam." International Journal of Middle East Studies 38, no. 4 (2006): 519-38. http:/ / www.jstor.org/stable/4129146.

Leisten, Thomas. "Between Orthodoxy and Exegesis: Some Aspects of Attitudes in The Shari'a Toward Funerary Architecture." Muqarnas Online 7, no. 1 (1989): 12-22. https:/ / doi.org/10.1163/22118993-90000245

Mājah, Abū 'Abdillāh Muhammad ibn Yazīd Ibn. Sunan Ibn Mājah I. Dār Ihyā' al-Kutub al- 'Arabiyyah, t.th.

Qayyīm (al), Ibn. Ighatsah al-Lahfan. Jeddah: Majma'a al-Fiqh al-Islāmī, 1432.

Rajab, Ibn. Al-Dhayl 'ala Tabaqat al-Hanabila. IV. al-Riyad: Maktabat al'Ubaykan, 2005.

Sa'dī (al), Abdurrahman ibn Nashir. Al-Qaul as-Sadid 'ala Syarkh alTaūhid, jilid 1. Daar al-Tsabat, 2014.

Shalabi, Muhammad Mustafa. Al-Madkhal fi al-Ta'rif bi al-Figh alIslāmì. Beīrūt: Dār al-Nahdah al-'Arabiyyah, 1985. 
Shawkani (al), Muhammad bin Abdullah. Nayl al-Awtar, "Kitab alJana'iz": Bab al-Nahy 'an Ittikhadh al-Masajid wa al-Sarj fi alMaqbarah, no. hadīth 1481. Beīrūt: Dār al-Kutub al-'Ilmiyyah, 1995.

Sijastani (al), Abū Daūd Sulaiman bin al-Asy'ats. Sunan Abū Daūd II. Beīrūt: Dār al-Fīkr, 2011.

Taīmīyyah, Ibn. Al-Radd 'ala al-Mantiqiyyin, jilid 1. Pakistan: Dār alTarjaman al-Sunnah, 1976.

Thahhan (al), Mahmud. Taisìr Musthalah al-Hadìts. Surabaya: Dār alKutub al-Islāmī, 2008.

Tim Penyusun, Al-Mausū'ah al-Fiqhiyah al-Kuwaitiyah, cet. 2. Kūwaīt: Wazarah al-Awqaf wa al-Syu'un al-Islāmīyyah, 1983.

Timo, Ebenhaizer I. Nuban. "The Tradition of Visiting the Graveyard: A Theological Study on the Ways of Timorese Christians Honoring and Remembering the Dead." In International Conference on Religion and Public Civilization (ICRPC 2018), (Atlantis Press, 2019): 16-21. https://doi.org/10.2991/icrpc18.2019.4

Tirmidzī (al), Muhammad 'Isya bin Saurah. Sunan al-Tirmidzī. Riyadl: Maktabah al-Ma'arif li al-Nasyr wa al-Tawzi'.

. Al-Jāmi' al-Kabìr Sunan al-Tirmidzī II. Bairut: Dār al-Gharby alIslāmī, 1998.

. Sunan al-Tirmidzī, "Kitab al-Jana'iz": Bab Ma Ja'a fi al-Rukhsah fi Ziyarah al-Qubūr, no. hadīth 1054. Riyadh: Maktabah al-Ma'arif, 1996.

Zaid, Bakar bin Abdullah Abū. Juz'un fi Ziyarāt al-Qubūr.

Zaydan, Abdul Karim. Al-Madkhal li Dirāsah al-Shari'ah al-Islāmīyyah, cet. 13. Beīrūt: Mu'assasah al-Risālah, 1996.

www.du3at.com/islamicbooks/3qeedah.htm. Diakses 06 Juni 2021. 